\title{
Foreign Ownership, Return Volatility, Trading Volume, and Risk of Stocks in Indonesia
}

Ahmad Maulin Naufa

Faculty of Economics and Business, Universitas Gadjah Mada, Indonesia

I Wayan Nuka Lantara

Faculty of Economics and Business, Universitas Gadjah Mada, Indonesia

*Corresponding author: ahmad.maulin.n@mail.ugm.ac.id

\section{A R T I C L E I N F O}

Article History:

Received 22 February 2018

Revised 8 July 2018

Accepted 8 August 2018

Keywords:

Indonesia, Foreign ownership, Return volatility, Volume, Risk.

JEL Code: G120, G150
A B S T R A C T

This study examines the relationship between foreign ownership and return volatility, trading volume, and risk of stocks at the Indonesia Stock Exchange (IDX). Panel data of selected companies listed on the LQ45 index of the IDX was employed for the period between 2011 and 2017. Foreign ownership was found to positively affect stock return volatility, trading volume, and risk. Hence, more substantial foreign ownership of stocks meant more drawbacks to Indonesian stocks. Therefore, there is a need for the Indonesian government to limit and regulate foreign shareholders in Indonesia.

\section{Introduction}

One of the financial instruments in the world entailing Indonesia is stock. Stock becomes an investment since it is expected to give a return to investors. Stock provides either a positive return (gain) or negative return (loss). Many factors like internal factors influence the changing of returns. One of the internal factors is ownership of stock. By improving technology, information, regulation, and relationship among countries, the ownership of stock is composed of both domestic and foreign investors. There are two reasons why foreign investors can influence stock price volatility: First, foreign investors have stronger 
encouragement and better ability to collect and process relevant information than domestic investors. Therefore they can see the fundamental aspects of price and increase price volatility. Second, they can enhance the governance and quality of financial information disclosures regarding investments. Globalization (opening of global markets to foreign investors) theoretically and empirically can provide benefits (positive) and losses (negative) to the economy of a nation.

Government policy related to foreign stock ownership in 2010 was capped at 49\% (maximum), albeit, it could have been higher. Thus, an Indonesian stock could be owned mainly by foreigners. Based on the statistical description of this research, the percentage of foreign ownership went up to 89 percent. Figure 1 shows the fluctuation of Indonesian stocks owned by foreigners in Indonesia between 2011 and 2017. This data was based on the Osiris Database.

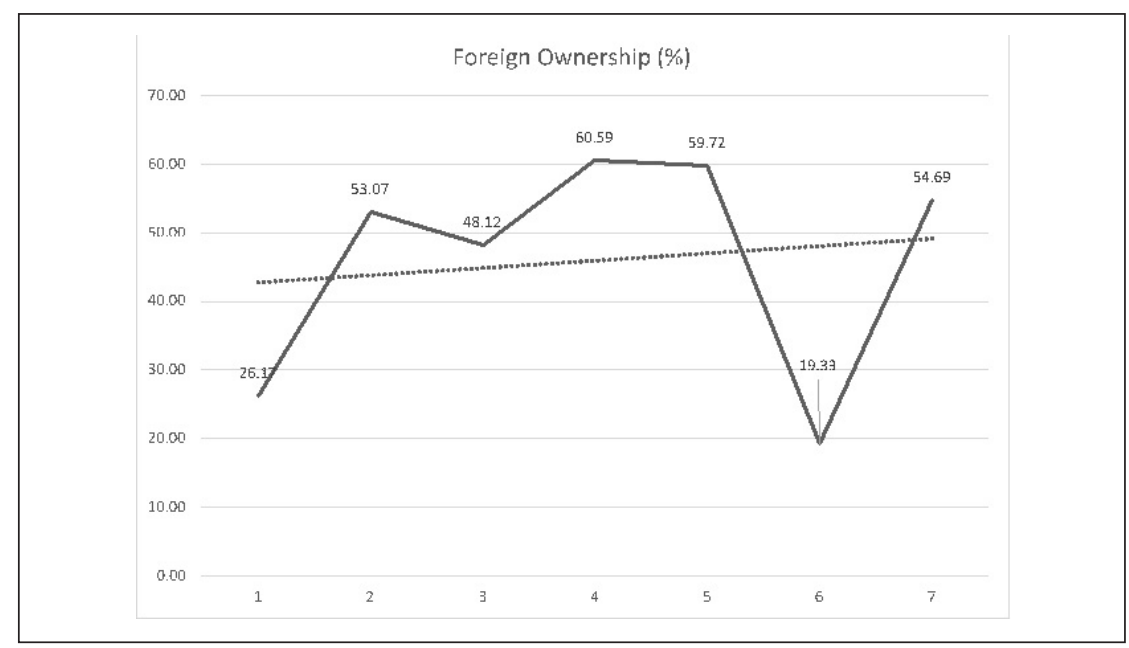

Figure 1. The Means Of Foreign Stock Ownership between 2011 and 2017 in Indonesia

The impact of foreign ownership on the risk and performance of company stocks is debatable. On the one hand, foreign ownership is supposed to affect stock return volatility as revealed by Wang (2007) that in Indonesia, the larger the stock owned by foreign investors, the larger the return volatility. Foreign investors affect stock market volatility in Indonesia since local investors tend to imitate them. Stocks chosen by foreign investors will surely be picked up by domestic investors presumably that more stocks will be bought, and then they become more volatile. Stocks selected by foreign investors are stocks with greater return potency than others; judgments which prove that foreign investors are better in valuation and processing relevant information, when choosing stock. Foreign ownership also creates a spillover effect-the introduction of 
foreign investors into the ownership structure could enhance the attractiveness of a company's stock and its trading volume (Rahman, 2008; Agarwall et al. 2009; Nurmalasarie, 2015).

On the other hand, Vo (2015) stated that foreign investors could stabilize the risk of companies via a monitoring mechanism, so that the higher the stocks owned by foreign investors, the lower the return volatility. Some argue that foreign ownership could reduce return volatility since it increases governance, risk sharing, monitoring, stabilization, and appropriate financial decision-making (Pambudi \& Smyth, 2009; Ang, Cole, \& Lawson, 2010; Solnik, 1974). Li, Nguyen, Pham and Wei (2011) also found in their study of 31 developing countries including Indonesia, that the higher the stocks owned by foreign investors, the lower the return volatility. Chen, $\mathrm{Du}, \mathrm{Li}$ and Ouyang (2011) suggest that foreign investors could reduce return volatility because of the strong commitment and monitoring of stocks that they owned. They stabilize and monitor to maintain lower volatility as the higher the volatility, the higher the risk of the stocks. Some previous studies (De Santis \& Imrohoroglu, 1994; Bekaert \& Harvey, 1997; Kim \& Singal, 2000) have shown that markets open to foreign investors tend to be stable, have low volatility, and do not impact return volatility. In short, despite the literature showing the different findings, the influence of foreign ownership toward return volatility remain inconclusive (Elliot \& Zhou, 2015).

Similar observations were made regarding the relationship between foreign ownership and trading volume and risk (Rahman, 2008; Agarwall et al., 2009; Nurmalasarie, 2015). Based on the observations, some researchers believe that foreign ownership can increase volume and risk, while other researchers believe that it leads to reduced volume and risk, while others argue that it did not affect the volume and risk of stocks.

The primary questions in this paper are whether foreign ownership affects those variables of stocks in Indonesia; whether the benefits of foreign ownership outweighs the disadvantages or vice versa; and whether or not Indonesia should limit foreign ownership of its stocks. This study intends to examine the relationship in more detail and.to seek answers to the questions raised by providing empirical evidence about the impact of foreign ownership on return volatility, volume, and risks due to contradictory findings (Wang, 2007; Li et al. 2011). This study also aims to explain further the upside and downside of foreign ownership in emerging markets like Indonesia. It could also extend the literature in this field as this study is about the relationship between foreign ownership and return volatility (Dvorak, 2005; Agarwall et al., 2009) in particular on trading volume and risk. It could also be enlarged empirically by using various estimation methods such as ordinary least square (OLS), generalized least square (GLS), random and fixed effects. 
Furthermore, this study can also become a reference point for policymakers in Indonesia to formulate regulations on foreign ownership of stocks in the Indonesian capital market. Lastly, this study could enhance the awareness of managers, regarding the role and impact of foreign ownership in their companies.

The probable implication of this study based on its findings is that foreign ownership of stock has a positive relationship with return volatility, volume, and risk both as an asset and equity. It means that the higher the foreign ownership, the more drawbacks to Indonesian stocks. Foreign shareholders are the source of risk on stocks, as they increase stock risk and return volatility. Therefore, restrictions and regulations should be imposed on foreign ownership of stocks in Indonesia. Based on the empirical findings, it was found that the GLS estimator fared better and was more efficient than OLS with regard to significance, R-squared, and standard errors. According to Wooldridge (2012), traditional assumptions like heteroskedasticity, multicollinearity, autocorrelation, and other assumptions should be considered when using OLS. Nevertheless, by using the GLS method we can ignore those assumptions taking into account the error terms and meeting those standard assumptions. The remainder of this paper comprises a literature review, research methodology, analysis of results, followed by a conclusion and some recommendations for further research.

\section{Literature Review}

Return volatility is a significant concern for investors and researchers. It is a crucial matter that must be noted by participants and policymakers, due to the impact of return volatility on the economic pressure of a country. High volatility was strongly related to the financial crisis in Asia in 1997 and the global crisis in 2008. Much equity in the developing markets is high in price volatility of its stocks, mainly since market uncertainty occurs during a crisis, which could be due to a political or financial problem. The capital of foreign ownership is also believed to be capable of causing extreme volatility in developing markets.

Nevertheless, we do not know the real impact of foreign ownership on the return volatility of stocks in Indonesia. As one of the developing markets, according to Vo (2015), it has three implications to Vietnam: Firstly, Vietnam is a country vulnerable towards such risks. Secondly, its regulations limit foreign ownership to $49 \%$. Lastly, the trend which has occurred is the disappearing limitation on investments with regards to capital flow and direct investment from foreign to developing countries. Examining stock price volatility on these has become an interesting topic to research.

It is also affected by many others factors such as ownership; bid asks spread, asymmetric information, spillover, future cash flow, and discount rate. Furthermore, Bae, Chan and $\mathrm{Ng}$ (2004) added that size of a company or market 
capitalization could also affect return volatility; that the larger the size of a company, the lower the return volatility, as it tends to be stable. Volatility could be measured by employing GARCH (Alexandridis, Saiannidis, \& Drimbetas, 2007). Volatility is commonly measured in the time series data, although it can also be conducted in cross-section.

It is difficult for foreign investors to own shares in other countries regardless of the attractiveness of inter-boundary investments (Vo, 2015). During the period between 1964 and 1999, underpriced stocks increased the return volatility of shares in the United States (Daniel, Hirshleifer, \& Subrahmanyam, 1998; Campbell, Lettau, Malkiel, \& Xu, 2001). Return volatility is affected by trust and assessment among investors, macroeconomic and economic activities, financial leverage, and trading volume. High volatility had a negative influence on riskaverse investors (Buraschi, Trojani, \& Vedolin, 2014). Higher return volatility was due to the spillover effect, i.e., too much trading activity (Alexandridis et al., 2007). Liberalization infinitely influenced return volatility (Arfoui \& Rejeb, 2015) and the investment ability of investors (Bae et al., 2004).

In short, many factors can affect return volatility, including ownership of stocks. Based on firm-level data, Chiang and Chan (2017) posited that foreign ownership in Taiwan had a negative relationship with stock return volatility due to its stabilizing effect. Foreign ownership diminishes volatility through stabilization, accumulation of better-quality information, controlling, reporting, and transaction of cost efficiency (Vo, 2015). Wang (2007) found that there was hardly any stabilization effect by foreign investors in Indonesia and Thailand during the Asian financial crisis in 1997. Instead, foreign investors attempted to reduce the volatility through risk sharing as they had financial capital, resources, technology and a strong commitment to long-term investment. Subsequently, this helped to improve corporate governance (Stulz, 1999, 2005; Doidge, Karolyi, \& Stulz, 2004) as well as liquidity and reduced price sensitivity (Hargis, 2002). Li et al. (2011) added that volatility was significantly lower (negatively correlated) when stocks were largely owned by foreign investors primarily in the developing markets through strong governance to reduce volatility (as higher volatility meant higher risk). They also ask the transparency of the financial system, accountability, and lower risk. Otherwise, the relationship between foreign ownership and volatility would be lower when shareholder monitoring is ineffective. Lastly, Hargis (2002) stated that volatility could be lower if foreign investors can increase the liquidity of stock and reduce price sensitivity. Therefore, our first hypothesis is:

H1. Foreign ownership has an adverse effect on return volatility.

Studies related to the relationship between foreign ownership and trading volume are limited. Lee and Chung (2017) studied foreign ownership and stock market liquidity by controlling trading volume. They found that the coefficient correlation between foreign ownership and daily trading volume was negatively 
significant. The reason was that although foreign traders increased the adverse selection, they reduced trading costs by increasing competition in the price discovery process. This is the first position where there is a negative correlation between foreign ownership and trading volume and vice versa, in the second position, there is a positive correlation between foreign ownership and trading volume.

There has been an explosion of foreign investors since the 2000s, due to financial liberalization and globalization (Vo, 2015). Foreign investment has an essential role in the stock markets of developing countries (Elliot \& Zhou, 2015). Shares have riskier returns in the global market and are more volatile (Li et al., 2011). Foreign investors tend to be followed by local investors since they perceive foreign investors as being more knowledgeable (Rahman, 2008). They can process stock information better, and consequently, can buy winner stocks and sell loser stocks (Grinbalt \& Keloharju, 2000; Jiang \& Kim, 2004). Shares owned by foreign investors increase trading volume (Kim, Kartaklas, \& Karanasos, 2005; Rahman, 2008). Kim et al. (2005) stated that there were several reasons why foreign investors could increase trading volume. Firstly, they have a role in the capital market; the increase in foreign investors by economic experts and policymakers is strongly expected to influence trading volume. It can lead trading volume (due to a spillover effect). The proxy to measure trading volume is the number of shares traded. Stock volatility is strongly related to trading volume when the financial crisis the trading volume (sell) was over great causes the extreme volatility. Arafouii and Rejeb (2015) stated that trading volume was positively associated with changing stock prices. Rahman (2008) asserted that the degree of foreign ownership influenced return and trading volume of stocks in the Indonesian capital market - the higher the foreign ownership, the higher the trading volume (an increase $0.285 \%$ in trading volume for every $1 \%$ increase of foreign ownership of stock).

Trading volume (short and long-term) correlated to ownership (domestic and foreign). Kim et al. (2005) asserted that the transparency of financial information could also help to attract foreign interest toward stocks. Indonesia has a transparent financial system, and is easy to access because of its cuttingedge technology. This could attract foreign investors to own stocks. The more foreign investors buy stocks, the more other investors (including local ones) buy. Therefore trading volume would increase. Agarwall et al. (2009) noted that the trading volume of foreign investors in Indonesia went up from $49 \%$ to $72 \%$ per se from the total volume of traded stocks based on an observation of 110 Indonesian stocks. In other words, the presence of foreign ownership makes trading volume more significant than before. Trading volume is a proxy of investor interest toward stock. Hence, we propose the second hypothesis as follows:

H2. Foreign ownership has a positive impact on trading volume. 
There are many reasons why foreign investors correlate negatively with the risk of stocks. One reason is that if domestic investors own the investment entirely, the risk is influenced entirely by these investors. Nevertheless, if both domestic and foreign investors can own it, the risk will be shared because of additional capital flow (Pambudi \& Smyth, 2009). Global investors create a positive sentiment in a country's stock market thereby increasing stock prices. Conversely, if they leave, it creates a negative sentiment in the market and stock prices would drop. Thus, net foreign sales or purchase of shares affects company returns (Nurmalasarie, 2015).

Risk depends on the owner, who must be able to tolerate risks by contributing to suggestions on an appropriate preference, decision-making, and capital structure to the company (Ang et al., 2010). Fiala and Havranek (2017) found that foreign ownership can be a source of risk, especially during a crisis. Despite this, companies can reduce their risks through international diversification of their equity portfolio (Solnik, 1974). International investments increases risk since it has an impact on the balance of a country's capital budget. This risk is not only faced by domestic investors but also foreign investors that have shares in the particular country. The return value would adjust the facedrisk value (Bachrach \& Galai, 1979; Anzim, 2007). Some researchers argued that opening the market to international investors could lead to liberalization, which in turn encouraged economic growth and risk sharing. Furthermore, they helped to reduce volatility of stocks by these actions (Li et al., 2011). Besides, capital flows, transparency, and regulation transformation could also reduce the risk (Pambudi \& Smyth, 2009). Thus, the third hypothesis is as follows:

H3. Foreign ownership has a negative impact on risk.

To illustrate the hypotheses, Figure 2 represents the hypotheses model:

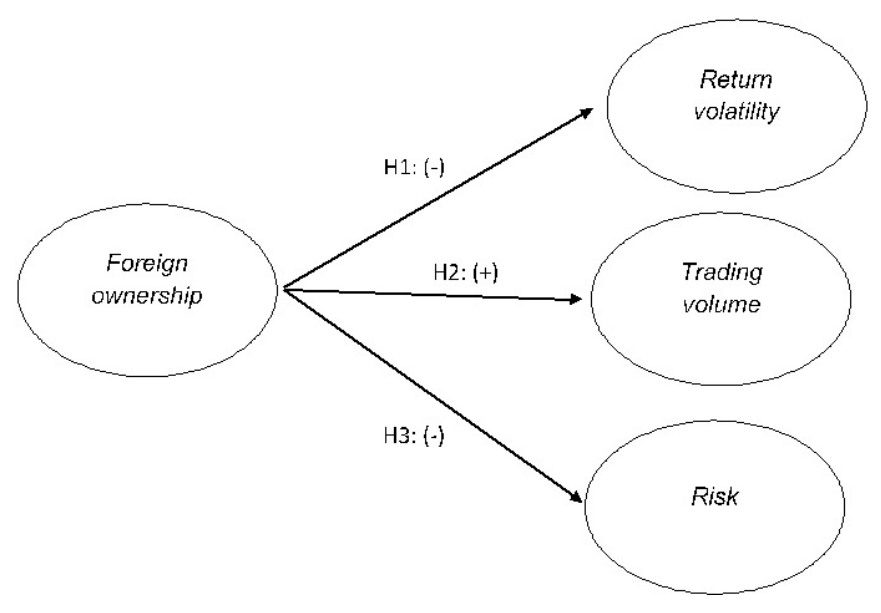

Figure 2. The Hypotheses Model 


\section{Research Methodology}

This research used the market level analysis; it employed stock market population from the Indonesia Stock Exchange (IDX) in LQ45. It is a benchmark index of Indonesian stocks and consists of 45 most active and liquid stocks in Indonesia. This study adopted the procedure employed by Li et al. (2011) who also used the Index- S\&P Index to select the samples. Purposive sampling technique was used to select the samples based on the following criteria: 1). Stocks were from non-financial companies 2). The stocks must appear in the index at least three times. This sampling technique was chosen since it can help to sort appropriate stocks based on the population of Indonesian stocks rather than all stocks entailing outlier data. According to Sekaran (2003), purposive sampling is a sampling technique conforming to certain criteria set by the researcher; it is a non-probability sampling design in which required information is gathered from specific targets or groups of a population based on some rational basis. According to Cooper and Schindler (2014), purposive sampling is a nonprobability sample that conforms to specific criteria. Therefore, the samples in this study comprised 59 samples of non-financial companies listed in the LQ45 Index between 2011 and 2017, selected from 414 firm-year observations.

The empirical research used panel data (a combination of time series and cross-section). This was similar with Li et al. (2011) who measured large data on foreign ownership using cross section and cross time variation to test the effect of foreign ownership on return volatility of stocks based on stock data gathered between 2002 and 2006. Thus, this study employed monthly data as follows:

Table 1. Summary of the Variables and Data Sources

\begin{tabular}{cc}
\hline Variables & Source \\
\hline LQ45 Index & $\underline{\text { www.idx.co.id }}$ \\
Company's return & Osiris Database \\
Foreign ownership & Osiris Database \\
Volume & Osiris Database \\
Return on Asset (ROA) & Osiris Database \\
Return on Equity (ROE) & Osiris Database \\
Leverage & Osiris Database \\
Size & Osiris Database \\
Turnover & Osiris Database \\
\hline
\end{tabular}

The measure of foreign ownership variable followed Li et al. (2011); this study used data from the Indonesia Central Securities Depository (PT Kustodian Sentral Efek I or, KSEI) that showed the name of the owner and the monthly percentage during the observation period. The owner is a citizen of a foreign country with stock(s) in another country or registered in a foreign company. 


$$
\text { Foreign ownership }=\frac{\sum \text { stock owned by foreign } n_{\underline{i}_{+}} * 100 \%}{\sum \text { total shares recorded }{ }_{i, t}}
$$

Vo (2015) was adopted to measure the return volatility, as follows:

$$
\text { return volatility }=\sqrt{\frac{1}{n-1} \sum_{i=1}^{n}\left(\text { return }_{i, t}-\text { mean }_{i, t}\right)^{2}}
$$

Volume was measured in accordance with Daigler and Willey (1999) by using a natural logarithm to keep no longer of data variation

$$
\text { Volume }=\text { Ln. volume }{ }_{i, t}
$$

Finally, major risks (equity and asset) were measured in accordance with Barry, Lepetit, and Tarazi (2011) using the standard deviation of return equity and asset.

$$
\begin{aligned}
& \text { Equity risk }_{i, t}=S D R O E_{i, t} \\
& \text { Asset risk }_{i, t}=S D R O A_{i, t}
\end{aligned}
$$

The chosen control variables were the variables which had potentially influenced return volatility: size, leverage, market to book value, and turnover (Vo, 2015; Li et al., 2011). Size is the measure of stock market capitalization ( $i n$. size). Leverage is the long-term liability ratio to total equity at the end of the year. Market to book is market ratio toward the book value per share in the last day of the year (MBV). Turnover is the number of shares outstanding (NSO) in one day divided by NSO in one year; this variable is a proxy to measure growth expectation of stock in the market (ln.turnover).

The model uses regression analysis (ordinary least square), this method examines the effect of the independent variable on the dependent variable. Nevertheless, in the final analysis generalized least square was utilized to solve some possible deviations of classical assumptions to yield a result deemed the best, linear, unbiased estimator (blue). Regression analysis was conducted using Eviews 10. The following is the empirical model of research:

Hypothesis 1

Yvolatility $_{i, t}=\alpha_{i, t}+\beta 1$ foreign $_{i, t}+\beta 2$ size $_{i, t}+\beta 3$ leverage $_{i, t}+\beta 4 \mathrm{MTB}_{i, t}+\beta 5$ turnover $_{i, t}+\mathrm{e}_{i, t}$ Hypothesis 2

Yvolume $_{i, t}=\alpha_{i, t}+\beta 1$ foreign $_{i, t}+\beta 2$ size $_{i, t}+\beta 3$ leverage $_{i, t}+\beta 4 \mathrm{MTB}_{i, t}+\beta 5$ turnover $_{i, t}+\mathrm{e}_{i, t}$ Hypothesis 3

YSDROA $_{i, t}=\alpha_{i, t}+\beta 1$ foreign $_{i, t}+\beta 2$ size $_{i, t}+\beta 3$ leverage $_{i, t}+\beta 4 \mathrm{MTB}_{i, t}+\beta 5$ turnover $_{i, t}+\mathrm{e}_{i, t}$ YSDROE $_{i, t}=\alpha_{i, t}+\beta 1$ foreign $_{i, t}+\beta 2$ size $_{i, t}+\beta 3$ leverage $_{i, t}+\beta 4 \mathrm{MTB}_{i, t}+\beta 5$ turnover $_{i, t}+\mathrm{e}_{i, t}$ 


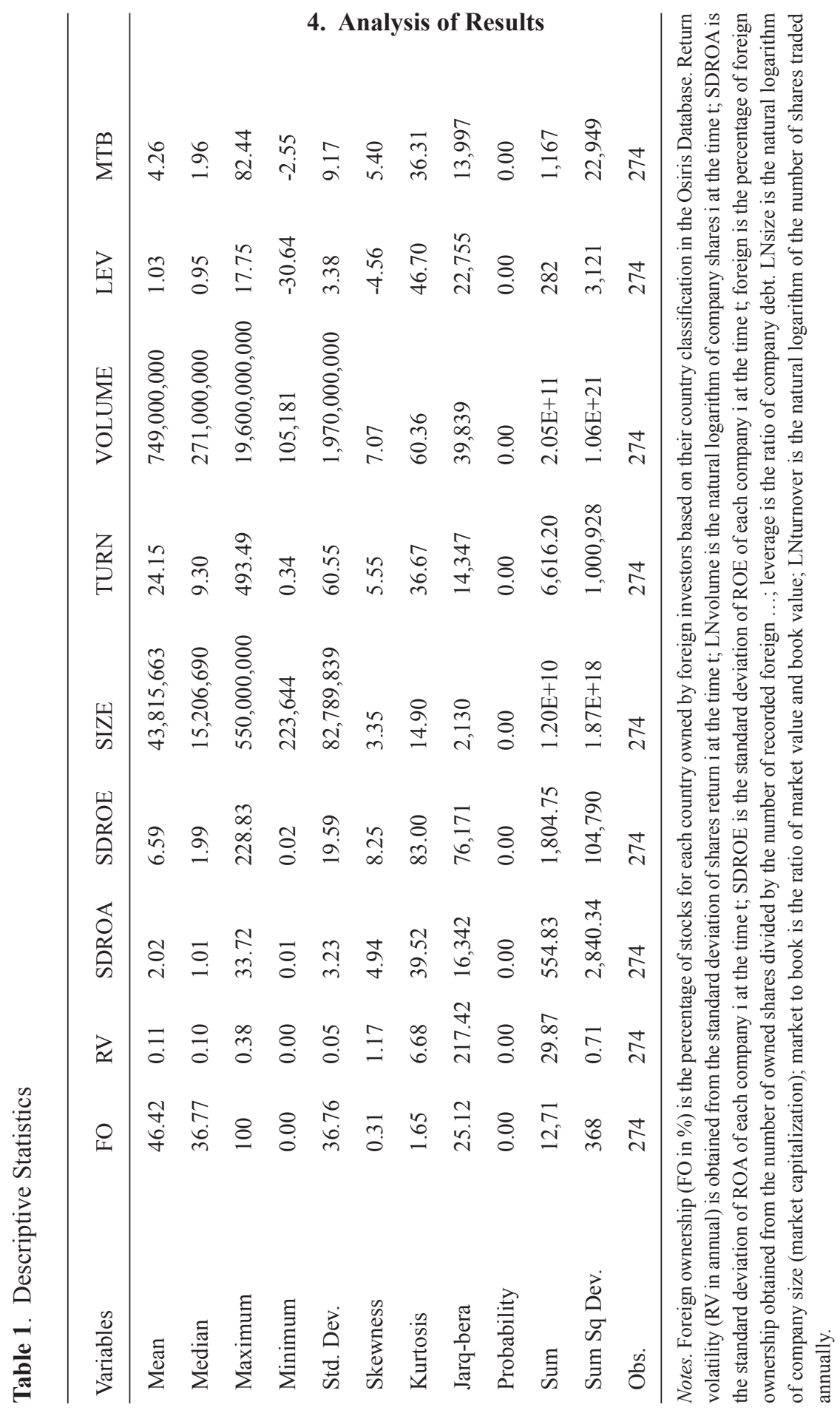


The descriptive statistics is presented in Table 1. The average percentage of foreign ownership is $46.42 \%$ with a maximum value of $100 \%$ as an independent variable. The average value of return volatility is 0.11 with a maximum value of 0.38 . The average dependent variable volume (natural logarithms of volume) is 749 million with a maximum value 19,600 (million). The average asset risk (standard deviation of ROA) is 2.02 with a maximum value of 33.72 . Hence, the average equity risk (standard deviation of ROE) is 6.59 with a maximum value of 228.83 .

Table 2 provides the preliminary correlation coefficient among variables in the analysis. First, there is a negative correlation between foreign ownership and both return volatility and trading volume. The higher the foreign ownership, the smaller the return volatility, and volume. Second, foreign ownership has a positive correlation with both asset and equity risk. Greater foreign ownership means higher risk. This finding needs further analysis to understand its significance.

Table 2. Coefficient Correlation between Variables

\begin{tabular}{|c|c|c|c|c|c|c|c|c|c|}
\hline & FO & $\mathrm{RV}$ & VOLUME & SDROA & SDROE & SIZE & LEV. & MTB & TURN. \\
\hline FO & 1.00 & & & & & & & & \\
\hline RV & -0.09 & 1.00 & & & & & & & \\
\hline VOLUME & -0.05 & 0.13 & 1.00 & & & & & & \\
\hline SDROA & 0.02 & -0.11 & 0.04 & 1.00 & & & & & \\
\hline SDROE & 0.01 & 0.03 & 0.05 & 0.29 & 1.00 & & & & \\
\hline SIZE & 0.31 & -0.35 & -0.09 & -0.06 & -0.05 & 1.00 & & & \\
\hline LEV. & -0.02 & -0.15 & 0.03 & 0.13 & 0.04 & 0.01 & 1.00 & & \\
\hline MTB & 0.20 & -0.26 & -0.09 & -0.07 & -0.05 & 0.59 & 0.10 & 1.00 & \\
\hline TURN. & -0.02 & -0.02 & -0.08 & 0.32 & 0.26 & -0.05 & 0.08 & -0.04 & 1.00 \\
\hline
\end{tabular}

Notes. Foreign ownership (\%) is the percentage of stocks for each country owned by foreign investors based on their country classification in the Osiris Database. Return volatility (annual) is obtained from the standard deviation of shares of return $i$ and time $t$; LNvolume is the natural logarithm of company shares $i$ and time $t$; SDROA is the standard deviation of ROA of each company $i$ and time $t$; SDROE is the standard deviation of ROE of each company $i$ and time $t$; foreign is the percentage of foreign ownership obtained from the number of owned shares divided by the number of recorded foreign ... ; leverage is the ratio of company debt. LNsize is the natural logarithm of company size (market capitalization); market to book is the ratio of market value and book value; LNturnover is the natural logarithm of the number of shares traded. 


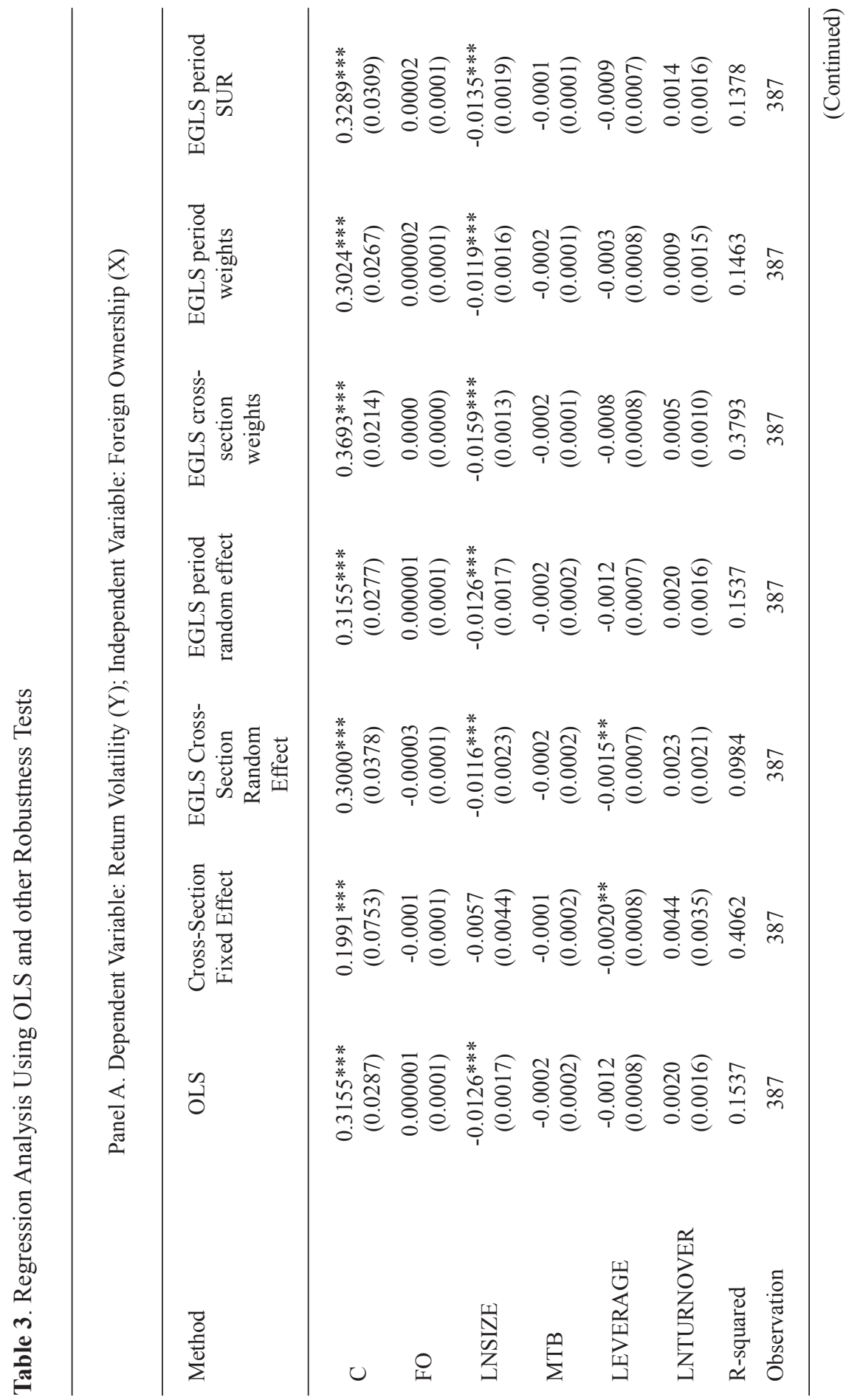




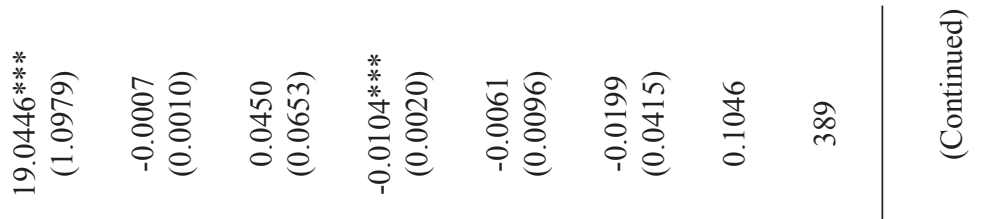

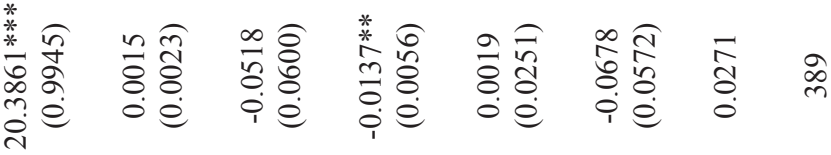

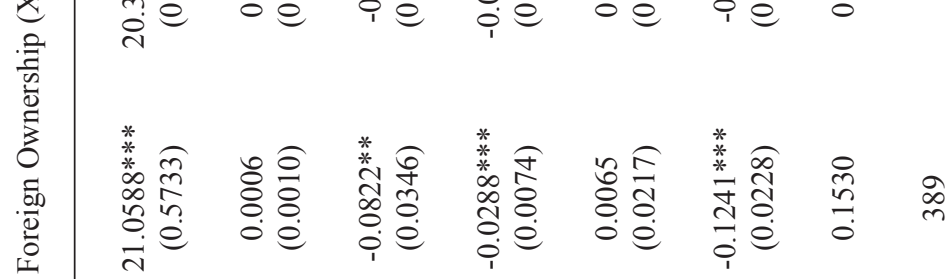

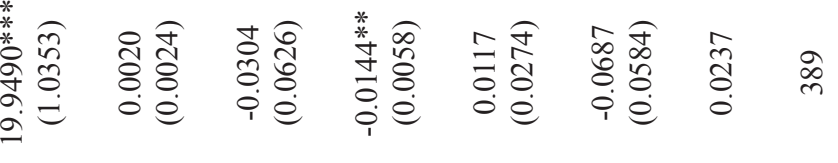

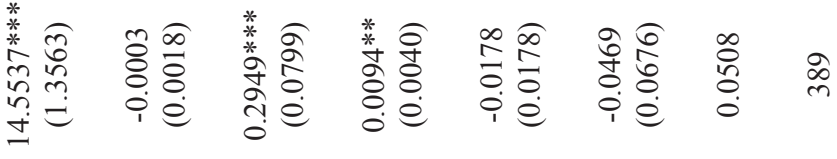

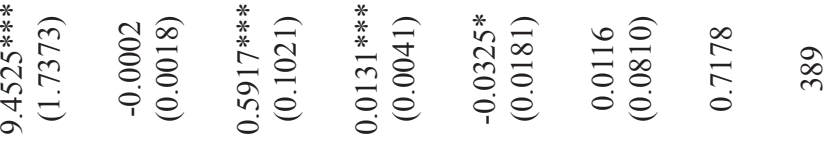

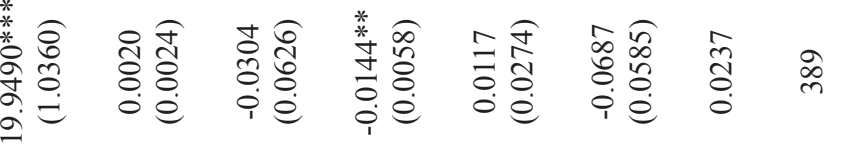

0 $\quad$ O 


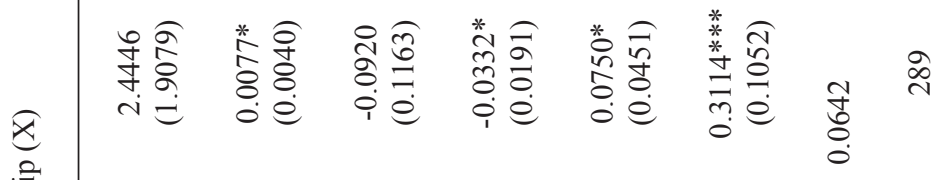

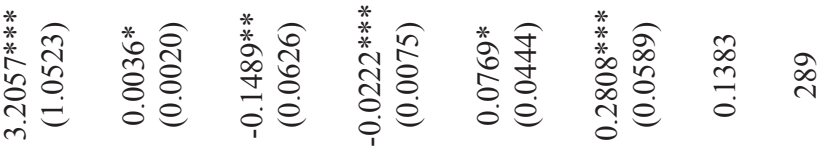

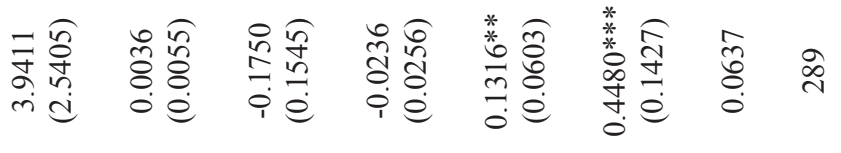

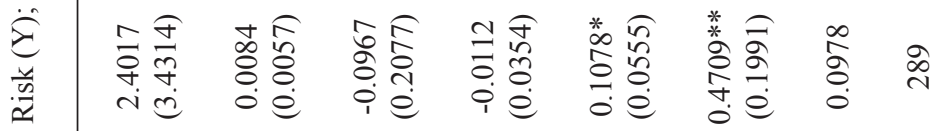
离

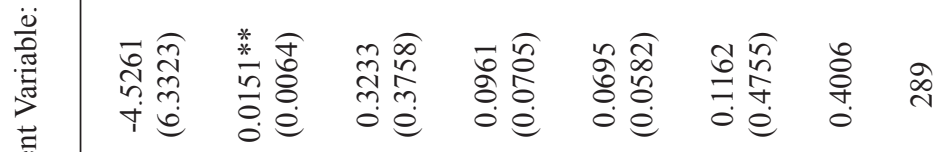
$\frac{\overrightarrow{0}}{\frac{0}{0}}$

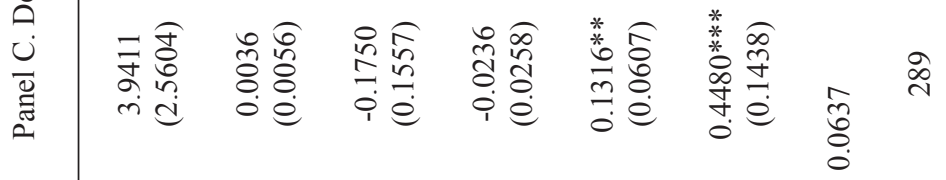

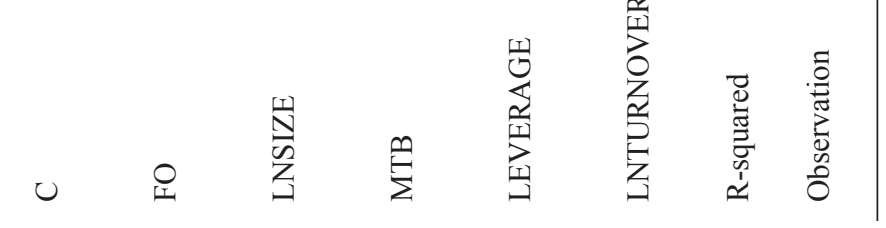




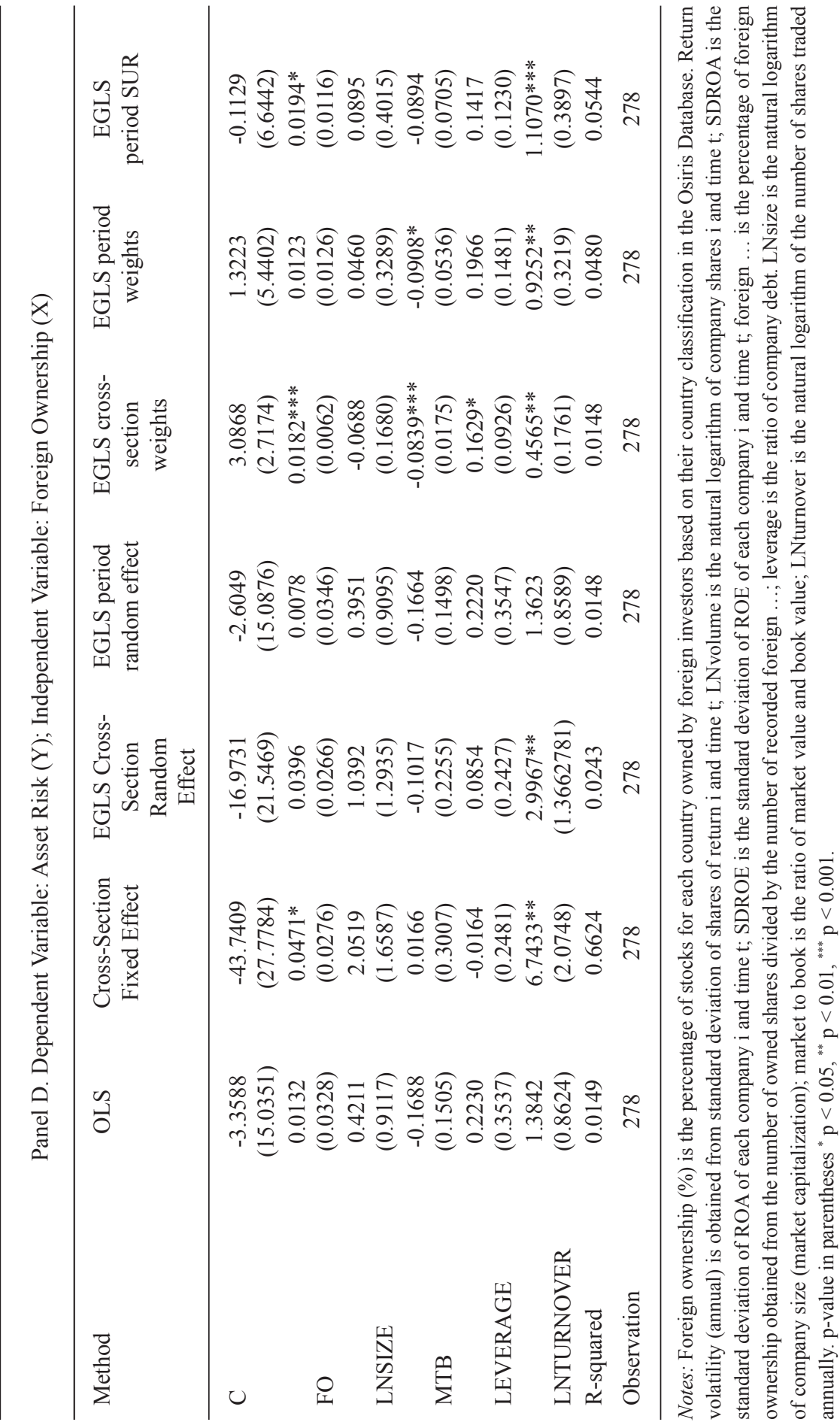


Panel A in Table 3 presents the regression analysis results (using various methods such as OLS, cross-section fixed effect, EGLS cross section random effect, EGS period random effect, EGLS cross-section weights, EGLS period weights, and EGLS period SUR) of panel data (across company-time). The analysis revealed that foreign ownership increased return volatility. This result confirmed findings by Bae et al. (2004) which revealed that higher foreign ownership correlated with higher volatility. Unlike Vo's (2015) research which was based on observations conducted for six years (from 2006 to 2012), this study only covered the period between 2011 and 2014. Vo (2015) considered daily returns, while this study considered monthly returns. Nevertheless, both studies were similar in that they analyzed data regarding stock in developing countries - Indonesia. Vo (2015) used ordinary least squared (OLS) and fixed effect regression analysis to perform estimations. This was the reason why this study conducted an additional fixed effect GLS regression in its analysis.

Furthermore, this study improved on Vo's (2015) method by using weights in the GLS regression analysis to observe whether the analysis results differed between least squared methods and other methods. In addition, this study compared which models were better to use using a scatter distribution of the research data. There were no extreme values using the OLS method.

The results provided some insights that foreign ownership enhances return volatility and therefore, foreign-owned shares have greater return volatility. Findings in the present study confirmed that foreign-owned stocks in Indonesia showed greater return volatility than domestic investor shares. According to Bekaert and Harvey (2000), foreign-owned shares made the economy fragile and extremely volatile. This vulnerability was due to exposure to global risk which occurred during the financial crisis of 1997-1998 because foreign investors owned most of the shares in the Indonesian market.

Consequently, the market would react when there was a financial shock in the foreign investor's country. Vo (2015) stated that financial globalization and liberalization was inevitable. For instance, in the past, Vietnam restricted foreign ownership of non-financial companies up to $49 \%$; however, that regulation is no longer in effect today. Moreover, the Indonesian economy still requires capital from foreign investors.

On the other hand, panel B in Table 3 shows that foreign ownership has a positive effect on trading volume. This finding supported studies by Vo (2015), who found that foreign investors significantly influenced trading volume in the financial markets of developing countries. Elliot and Zhou (2015) stated that a rise in foreign investors increased trading volume. Some financial economists and decision-makers also found that increased foreign investment resulted in higher stock price volatility. Analysis from this study supported the argument that increasing foreign ownership raised the trading volume of stocks. This result indicated that foreign investors in Indonesia tend to hold stocks for the shortterm. 
Vo (2015) stated that although foreign investors live away from the country where they purchased shares, an open financial system, regulatory support, and technological progress can help them monitor their stocks. These factors open opportunities for foreign investors to own more shares. If the volume of shares owned by global investors increased, they could still control these stocks via technological and financial system support. Agarwall et al. (2009) noted that the trading volume of foreign investors in Indonesia could reach between $49 \%$ and $72 \%$ in their observation using 110 stocks. Moreover, Arfaoui, and Rejeb (2015) stated that trading volume is a proxy of investor interest and not shares. A higher trading volume indicates that the shares are valuable and vice versa. Therefore, trading volume positively influences stock price movements.

Panel C in Table 3 shows that foreign ownership significantly influences (p-value $<0.01$ ) asset risk (standard deviations of ROA). The analysis indicated that the higher the number of foreign-owned shares, the more substantial the asset risk. This insight illustrated that more foreign investors do not help to reduce risk, specifically the risk - asset risk for the company. This contradicted findings from Ang et al. (2010) who found that foreign stock owners reduced any associated risks by their preference, proper decision-making and optimal capital structure policy. Therefore, based on this study, foreign shareholders are the source of risk since they bring considerable risk from their respective countries to Indonesia.

Panel D in Table 3 shows that foreign ownership significantly enhances (p-value $<0.01$ ) the equity risk (standard deviation of ROE), the larger the foreign ownership, the higher the equity risk. This result contradicted Li et al. (2011), Pambudi and Smyth (2009), Ang et al. (2010), and Solnik (1974) who found that foreign ownership reduced stock risk due to the foreign investors' role in good governance, monitoring, stabilization, and risk sharing.

Robustness was conducted to mitigate endogeneity matters, to check and reconfirm results from the regression analysis. In accordance with Vo (2015), Kang and Stulz (1997), and Li et al. (2011), robustness assisted in validating the analysis results of this study to prove its consistency. Vo (2015) also compared various least square techniques, such as the common, fixed, and random effect methods. The results of this study concurred with studies by Wang (2007) and Bae et al. (2004) where the more substantial the foreign ownership, the higher the return volatility. Since foreign investors are speculators, they also face the risk of exchange rates, regulations, and politics which not only occur in their country, but also in the country in which stocks are traded. Besides, the increase of foreign ownership elevates fundamental risks (assets and equity risk), since the shares owned by foreigners are influenced by risk factors in the country where they live, or in other words more susceptible to global risk factors. The following are the details. 


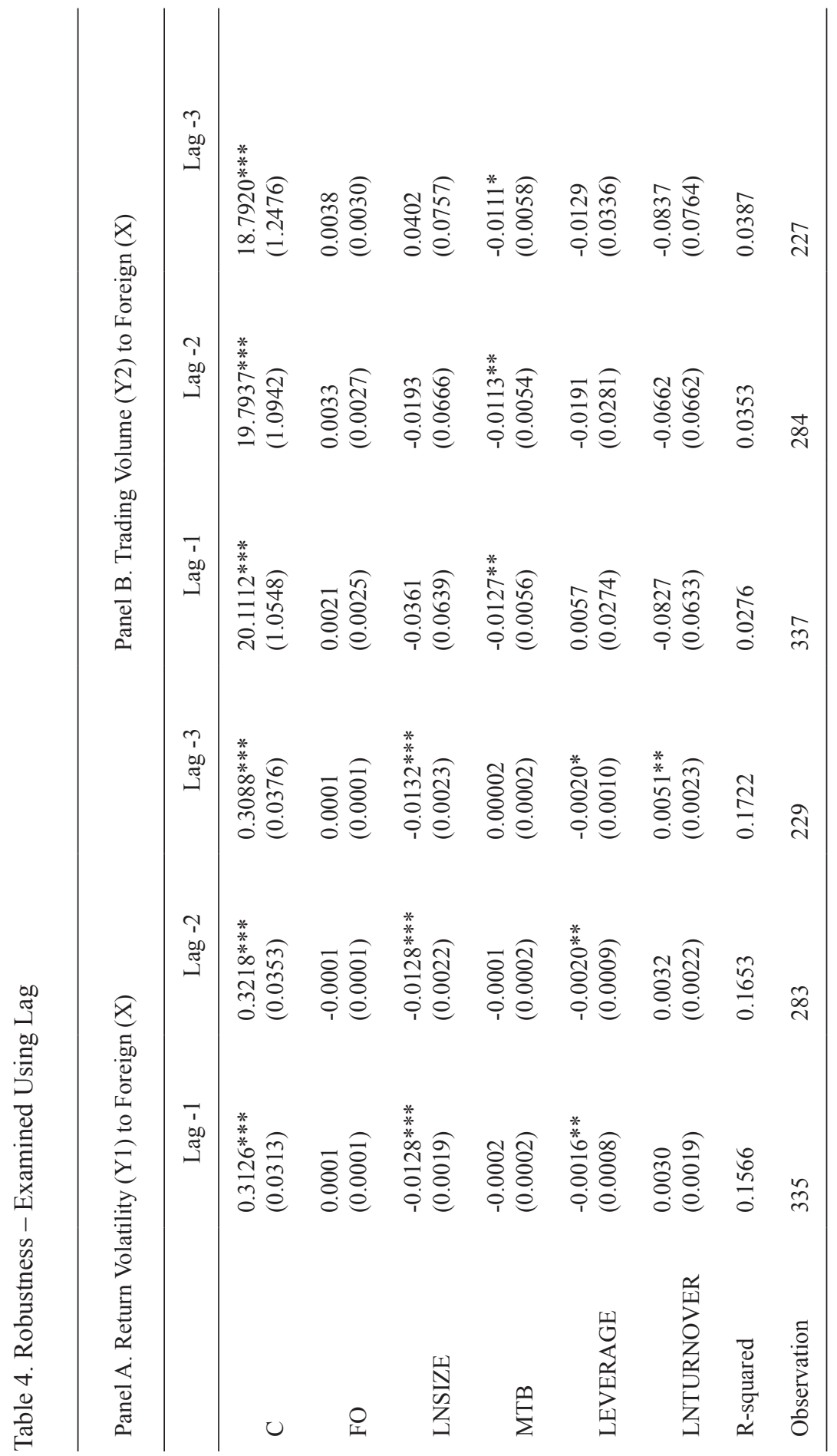




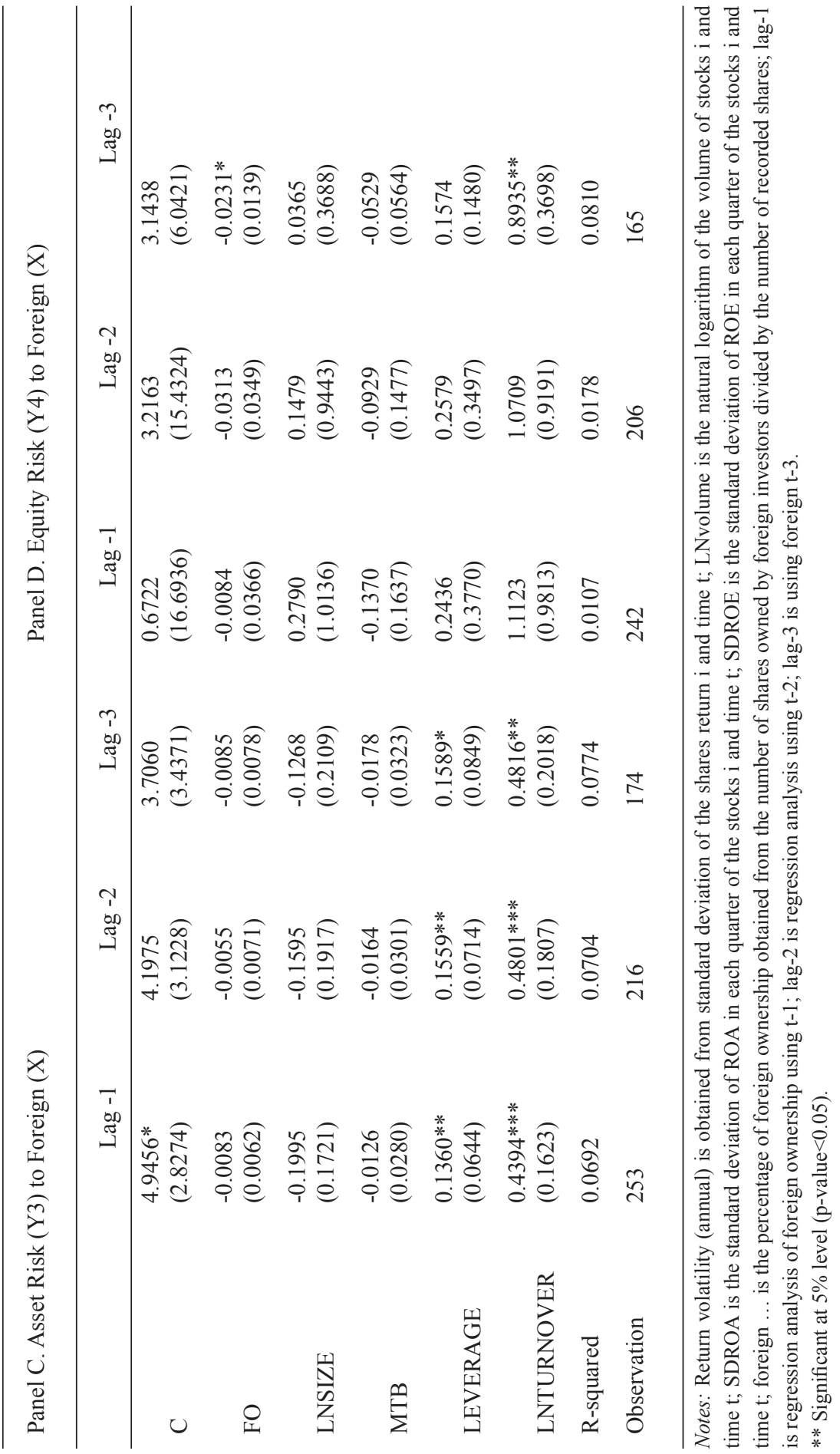


Table 4 presents the analysis of results obtained using lag, wherein the dependent to independent variables were tested in the previous period ( $t-1, t-2$, and $\mathrm{t}-3)$.

The results showed that previous foreign ownership in the present year had no significant impact on return volatility, trading volume, and risk of stock in Indonesia for one to three years ( $p$-value $>0.05$ ). Thus, the impact of foreign ownership only exists for a short period (in the present year) rather than for the long-term (in the future). This test was conducted in accordance with the study by Wooldridge (2012) where if the data possessed a time series nature, i.e., the value or event in the present year could impact the value or event in succeeding years. The details are below.

\section{Conclusion and Discussion}

From this research, it can be concluded that increased foreign ownership increases return volatility, trading volume, and risk (assets and equity) in Indonesian companies. Banks were excluded from this study since they have rather different and stringent regulations than other sectors. Foreign investors increase return volatility, and trading volume since foreign-owned shares could attract other investors, particularly domestic investors. Therefore, stock prices would rise, and returns would become more volatile. Furthermore, the risk would be higher if foreign investors increase since foreign investors do not reduce risk. Instead, they bring global risk and thus, become the source of risk.

Based on the findings of this study, globalization of Indonesian stocks increases all the three dependent variables which in turn can benefit policymakers. Despite this, policy makers, should tread carefully as foreign ownership of stocks may have drawbacks, and therefore the Indonesian government should limit and regulate these stocks, strictly. For practical considerations, Indonesian companies should gauge foreign shareholders if they have equities in their company. Literature on the relationship between foreign investors and volumerisk of stock has been extended in this empirical study as studies related to this topic were quite limited. This study also revealed that GLS methods are better and more efficient than OLS.

There were some limitations in this paper. For instance the data used were yearly data because foreign ownership data in the Osiris database had only yearly ones. This is in comparison to, for instance Indonesia, where more detailed data up to the monthly level can be obtained. Another limitation was the type of investors; this study only used total foreign ownership. In addition, the samples used were from the LQ45 index in Indonesia, however, this does not apply to all Indonesian companies. Besides, this research was conducted only in Indonesia. Furthermore, as there are various other methods and robustness techniques, the robustness tests selected may have been restricted in certain methods. 
For further research, this study recommends improving the data level up to monthly data, using a comparison database source including different variables, and extending estimation methods, models, proxies and observation time range.

\section{References}

Agarwall, S., S. Farcloth., C. Liu., \& S. G. Rhee. (2009). Why do foreign investor underperform domestic investor in trading activities? Evidence from Indonesia. Journal of Financial Market, 12, 32-53.

Alexandridis, A., Saiannidis, N., \& Drimbetas, E. (2007). Impact of international volatility and the introduction of individual stock futures on the volatility of a small market. Spoudai, 57, 119-135.

Ang, J., Cole, R., \& Lawson, D. (2010). The role of owner in capital structure decisions: An analysis of single owner corporations. The Journal of Entrepreneurial Finance, 14, 1-36.

Anzim, M. (2007). Foreign investment risks and gains. Economic Review, 8.

Arfaoui, M., \& Rejeb, A. B. (2015). Return dynamics and volatility spillovers between forex and stock market in Mena countries: What to remember for portfolio choice. International Journal of Management and Economics, 46, 72-100.

Bachrach, B., \& Galai, D. (1979). The risk-return relationship and stock prices. Journal of Financial and Quantitative Analysis, 14, 421-441.

Bae, K. H., Chan, K., \& Ng, A. (2004). Investibility and return volatility. Journal of Financial Economics, 71, 239-263.

Barry, T. A., Lepetit, L., \& Tarazi, A. (2011). Ownership structure and risk in publicly held and privately-owned banks. Journal of Banking and Finance, 35, 1327-1340.

Bekaert, G., \& Harvey, C. (1997). Emerging equity market volatility. Journal of Financial Economics, 43, 29-78.

Buraschi, A., Trojani, F., \& Vedolin, A. (2014). When uncertainty blows in the orchard: Comovement and equilibrium volatility risk premia. The Journal of Finance, 19, 101-137.

Campbell, J. Y., Lettau, M., Malkiel, B. G., \& Xu, Y. (2001). Have individual stocks become more volatile? An emprical exploration of idiosyncratic risk. The Journal of Finance, 56, 1-43.

Chen, Z., Du, J., Li, D., \& Ouyang, R. (2011). Does foreign institutional ownership increase return volatility? Evidence from China. Journal of Banking and Finance, 37, 660-669.

Chiang, Y. C., \& Chan, M. H. (2017) Foreign ownership and firm-level stock return volatility in Taiwan. Investment Management and Financial Innovations, 14(3), 261-269. 
Cooper, D. R., \& Schindler, P. S. (2014). Business research methods (12th ed.). New York: McGraw-Hill Irwin.

Daigler, R. T., \& Wiley, M. K. (1999). The impact of trader type on the futures volatility-volume relation. Journal of Finance, 14, 2297-2314.

Daniel, K., Hirshleifer, D., \& Subrahmanyam, A. (1998). Investor psychology and security market under and overreactions. The Journal of Finance, 23, 1839-1885.

De Santis, G., \& Imrohoroglu, S. (1994). Stock return and volatility in emerging financial markets. Discussion Paper No. 93. University of Southern California.

Doidge, C., Karolyi, G. A., \& Stulz, R. M. (2004). Why are foreign firms that list in the U.S. worth more? Journal of Financial Economics, 71, 205-238.

Dvorak, T. (2005). Do domestic investor have an information advantage? Evidence from Indonesia. Journal of Finance, 70, 817-858.

Elliot, R. J. R., \& Zhou, Y. (2015). Co-location and spatial wage spillovers in China: The role of foreign ownership and trade. World Development, 66, 629-644.

Grinbalt, M., \& Keloharju, M. (2000). The investment behavior and performance of various investor types: A study of Finland's unique data set. Journal of Financial Economics, 55, 43-67.

Hargis, K. (2002). Forms of foreign investment liberalization and risk in emerging markets. Journal of Financial Research, 25, 19-38.

Jiang, L., \& Kim, J. B. (2004). Foreign equity ownership and information assymetry: Evidence from Japan. Journal of International Financial Management and Accounting, 15, 184-213.

Kang, J. K., \& Stulz, R. M. (1997). Why is there a home bias? An analysis of foreign portfolio equity ownership in Japan. Journal of Financial Economics, 46, 3-28.

Kim, E. H., \& Singal, V. (2000). Stock market openings: Experience of emerging economies. Journal of Business, 7, 25-66.

Kim, J., Kartaklas, A., \& Karanasos, M. (2005). The volume volatility relationship and the opening of the Korean stock market to foreign investor after the financial turmoil in 1997. Asia Pacific Financial Market, 12, 245-271.

Lee, J., \& Chung, K. H., (2017). Foreign ownership and stock market liquidity. International Review of Economics and Finance, 1-41.

Li, D., Nguyen, Q. N., Pham, P. K., \& Wei, S. X. (2011). Large foreign ownership and firm level stock return volatility in emerging markets. Journal of Financial and Quantitative Analysis, 46, 1123-1155.

Nurmalasarie, E. (2015). Pengaruh Net Foreign Buy/Sell pada Return Saham Perusahaan yang Terdaftar dalam Indeks LQ-45 Bursa Efek Indonesia (BEI). (Tesis tidak dipublikasikan). Universitas Gadjah Mada, Yogyakarta, Indonesia. 
Pambudi, D. \& Smyth, R. (2009). Making Indonesia more attractive to foreign investors: A computable general equilibrium analysis of reducing the premium in Central Java. RURDS, 20, 226-240.

Rahman, P. (2008). Analisis Pengaruh Tingkat kepemilikan Investor Asing terhadap Return Saham dan Volume Perdagangan Saham di Bursa Efek Indonesia. (Tesis tidak dipublikasikan). Universitas Gadjah Mada, Yogyakarta, Indonesia.

Sekaran, U. (2003). Research methods for business: A skill-building approach (4th ed.). John Wiley \& Sons, Inc. America.

Solnik, B. (1974). Why not diversify internationally rather than domestically? Financial Analysis Journal, 30, 48-54.

Stulz, R. M. (1999). Globalization of equity markets and the cost of capital. New York Stock Exchange Conference on Global Equity Equipment, New York.

Stulz, R. M. (2005). The limits of financial globalization. Journal of Finance, $12,8-25$.

Vo, X. V. (2015). Foreign ownership and stock return volatility-evidence from Vietnam. Journal of Financial Management, 30, 101-109.

Wang, J. (2007). Foreign ownership and volatility dynamics of Indonesia stocks. Asia Pacific Financial Markets, 14, 201-210.

Wooldridge, J. M. (2012). Introductory econometrics: A modern approach $\left(5^{\text {th }}\right.$ ed.) South-Western, Cengage Learning. 